las abundantes notas que acompañan los textos. A pesar de sus limitaciones esta atitelogía ha de ser de una gran utilidad para los cursos introductorios de literatura hispanoamericana en universidades y colegios de U. S. A. y otros países.

JAmes Higgins

\title{
University of Liverpool
}

Guillermo Cabrera Infante. Tres tristes tigres. Batcelona: Editorial Seix Barral, Biblioteca Breve, 1967.

Tres tristes tigres es una novela con historia, y en un sentido muy amplio, pues los azares que han conducido a su versión final forman parte de un importante capítulo de historia del siglo $\mathrm{xx}$-el que nos está tocando vivir-, caracterizado por la lucha del individuo contra presiones de todo género, particularmente políticas, lucha (verdadera agonía) que refleja una buena porción de la literatura de nuestro tiempo. En un número del magazine literario Lunes de Revolución (suprimido por el gobierno cubano en 1961) había aparecido un "avance" de la novela, bajo el título de "Ella cantaba boletos", que, continuando la línea de algunos de sus relatos anteriores, como el brillante "Josefina, atiende a los señores", mostraba, sin embargo, un Cabrera Infante distinto, o mejor, un escritor ya maduro, en plena posesión de sus recursos creadores. Pero cuando en 1964 se anunció que la novela de Cabrera Infante, titulada entonces Vista del amanecer en el trópico, había recibido el premio Biblioteca Breve de la Editorial Seix Barral, la noticia suscitó en mi encontradas emociones. Por una parte, me alegraba de que el premio hubiera correspondido a un cubano, por añadidura miembro de mi generación y viejo amigo, con quien había participado en más de una de esas empresas artísticas que en nuestro país requieren tenacidad y paciencia infinitas, como la de la "Cinemateca de Cuba" en la década de los cincuenta. Por otra, el título sugería que se trataba de una novela concebida "a programa" - programa político-social, claro está-, como tantas otras escritas en "Cuba a partir de 1959 , y me costaba trabajo aceptar que un talento como el de Cabrera Infante, cuya cualidad más destacada era su independencia, se hubiera plegado a esa moda, o modo, que termina, en la mayoría de los casos, por reducir al artista a un mero artesano de la fórmula y el tópico. Afortunadamente $-\mathrm{y}$ el novelista lo ha aclarado hace poco, en la entrevista con Emir Rodríguez Monegal aparecida en Mundo Nuevo (Núm. 25, julio 1968) - Cabrera Infante ha optado por el ca. mino cada día más difícil de la fidelidad a sí mismo, y esta que leemos es la versión revisada, o rehecha, del manuscrito primero; eliminada toda apriorística connotación político-social, el resultado es un testimonio, a la vez lúcido y apasionado, de ciertos aspectos de la vida cubana, ante los cuales no se pide al lector una simplista aprobación o condena, sino una comprensión que, como toda auténtica manera de comprender, ha de nacer de ese perfecto equilibrio entre el amor y la repulsión generalmente denominado espíritu de tolerancia. $Y$ ya que he hablado de independencia en Cabrera Infante, debo añadir que, entre sus 
muchas virtudes, tiene esta novcla la de ser completamente original, lo cual no significa que no esté relacionada en más de una manera -afirmar otra cosa sería paladina tontería-, con una abundante masa de literatura, anterior a coetánea, sino que responde a la necesidad genuina de estructurar artísticamente una particular "visión del mundo"; virtud excepcional en estos tiem. pos de nuevos ismos y programas (no precisamente políticos), que a veces dan la impresión de preceptivas, por los que atraviesa la literatura hispanoamericana.

Tres tristes tigres, dice la nota de la contraportada, "es una celebración de la noche". La frase, si se va un poco más allá de su sentido literal, es de una felicidad extraordinaria. Porque el libro es en el fondo como un rito exorcístico con que el autor ha querido purificarse - catarsis en la que participa el lectorde ese demonio, cuya representación se halla aquí en la noche, que vive en nosotros en oposición a nuestro lado angélico, simbolizado por la luz, por el día. Más todavía, el lector, en tanto explorador de la tealidad cubana presentada por la novela, realiza, guiado por Cabrera Infante, un descenso al infierno de La Habana nocturna, un verdadero "viaje al fin de la noche", que le revela ese fondo de delirio y violencia, sensualidad y tristeza animal -quizá síntomas fatales de los trópicos, favorecidos en Cuba por su condición de isla estratégica del Caribe, que la convirtió en centro de trasiego marinero, escala obligada de expediciones al continente e importante base militar, con todas sus secuclas-, rasgo de la fisonomía nacional que los cubanos nos hemos empeñado ridículamente, durante generaciones, en rechazar. Ya había descubierto ese reverso de las Cubas paradisíacas, agrarias, guerreras o patricias, Virgilio Piñera en su extenso poema la isla en peso, que uno de los acuñadores de categorías oficiales de la cultura cubana consideraba hace diez años como un testimonio falseado de la isla. Cabrera Infante presenta ahora estas fuerzas oscuras utilizando el medio más complejo, más analítico si se quiere, de la novela. En este contexto alcanzan su valor exacto imágenes como la de esa personificación del mundo sombrío de la isla que es Cuba Venegas, de quien nos dice el autor que "es mejor, mucho mejor ver a Cuba que oírla y es mejor porque quien la ve 1 ama, pero quien la oye y la escucha y la conoce ya no puede amarla, nunca"; o aquella del coctel llamado "mojito" ("agua, vegetación, azúcar [prieta], ron y río artificial"), visto como una "metáfora de Cuba". Se explica así también que no falte en esta evocación de monstruos de la noche, el emblema del tradicional leviatán: La Estrella, esa "Ballena Negra" que, como las sirenas míticas, encanta con su voz en las profundidades lóbregas de los bares.

Desde este punto de vista se justifica que la obra, abandonando casi en abso. luto la narración de desarrollo lineal, haya adoptado esa forma de improbable rompecabezas o caleidoscopio, que hace de su lectura (como de la de su, en cierto modo, afín Rayuela, de Julio Cortázar) un delicioso ejercicio imaginativo e intelectual. $Y$ ies que el lenguaje, un lenguaje siempre cambiante - diálogo populat o culto; epístolas iletradas, monólogo interior, memoria autobiográfica, fragmento de sesión psiquiatrica, parodias literarias, todo ello atravesado por estimulantes juegos de palabras- constituye la única sustancia que la estructura. Se afirma en la nota antes mencionada que los verdaderos personajes de la novela son "la nos. talgia, la literatura, la ciudad, la música y la noche y, a veces, esa forma actual de arte que parece reunirlas en una sola cosa: el cine"; cabe añadir que todos estos elementos son el vario reflejo -imagen multiplicada en una serie de espe. 
jos- del autor, quien, en lugar de pretender ocultarse tras el mundo de la ficción, como, por lo regular, ha ocurrido desde Henry James hasta el extremo objetivismo de Robbe-Grillet, encuentra especial placer en llamar la atención sobre su presencia, o más exactamente, omnipresencia. Así, los personajes más notables -Eribó, Códac, Silvestre, Cué- son encarnaciones diversas del Verbo de ese Jacques Va. ché del trópico llamado Bustrófedon, que no es, a fin de cuentas, sino proyección del genio proteico de Cabrera Infante. Poco importa que estos personajes estén inspirados en algunos rasgos de personas reales, vivas o muertas, cuya identificación llevaría a considerar el libto como un roman à clef (o roman à Klee, según diría Bustrófedon, quien recuerda tanto al difunto poeta Baragaño); por efecto de esa especie de taumaturgia o alquimia operada por la creación artística, esos seres medio reales se han trasmutado en otras tantas hipóstasis de su creador, de modo que, parodiando la fórmula teológica de la Trinidad, se podría hablar de varias personas y un solo tigre verdadero. Me he extendido sobre esta peculiaridad del libro, para prevenir a sus futuros lectores de aplicarle el metro de las psicologías y las sociologías. Ahora bien, si el héroe principal de la novela resulta ser el autor, y si el texto no es en verdad una autobiografía, se preguntará el lector cuál es la actitud recomendable para leerla. Julio Ortega, en su reseña de Mundo Nuevo (número citado antes), propone una lectura "abierta" del libro. Sé que estos adjetivos suelen ser peligrosos por imprecisos, pero yo soy partidario de una lectura lo más "cerrada" posible; el lector de TTT ha de obedecer sin objetar las órdenes del autor, sumergirse en el ámbito nocturno de la obra y dejarse arrastrar por su implacable torrente de sorpresas verbales. En otras palabras, abandonar toda resistencia. Creo que sólo así le será dado, como al personaje de Silvestre al final de la novela, cerca ya del amanecer, encontrarse en disposición de recibir la luz (que para este personaje significa una ruptura con su vida anterior), tras la experiencia demoníaca de la noche.

University of Pittsburgh

JuLio Matas

Arqueles Vela. Poemontaje. México: Ediciones de Andrea. Colección Espiral, 1968.

Poemontaje nos vuelve a poner en contacto con una voz poética que no se dejaba oír desde hacía más de 25 años. Como se recordará, Arqueles Vela, uno de los miembros del movimiento estridentista mexicano, publicó, muy espaciadamente, dos obras en verso: El sendero gris y otros poemas (1921) y Cantada a las mucbachas fuerte [sic] $y^{\prime}$ alegres de México (1940). Pero el creador no ha dejado de seguir produciendo, alternando la ficción en prosa (Cuentos del dia y de la nocbe y El picaflar) con la teoría y la crítica literaria (Análisis de la expresión literaria).

La distancia temporal en la publicación de cada libro poético ha hecho, sin duda que la voz de Arqueles Vela aparezca siempre renovada o distinta. Si en El sen- 